\title{
PENYELESAIAN SENGKETA TANAH ULAYAT PADA PROYEK PEMBANGUNAN JALAN DI PAPUA BARAT (STUDI KASUS DI KABUPATEN SORONG PAPUA BARAT).
}

\author{
Abdilbar Isnaini Wijaya \\ Magister Kenotariatan Universitas Brawijaya \\ Jln. Veteran Malang, Brawijaya \\ Malang, Jawa Timur \\ Email:abdilbarr07@yahoo.com

\section{Iwan Permadi} \\ Magister Kenotariatan Universitas Brawijaya \\ Jln. Veteran Malang, Brawijaya \\ Malang, Jawa Timur \\ Email : -

\section{R. Imam Rahmat Safi'i} \\ Magister Kenotariatan Universitas Brawijaya \\ Jln. Veteran Malang, Brawijaya \\ Malang, Jawa Timur \\ Email : -
}

\begin{abstract}
This study is conducted to know how the dispute settlement of communal land towards road construction project in Sorong Regency, West Papua. Moreover, the study has purposes to know and comprehend the implementation of dispute settlement and factors of land dispute in the project aforementioned. Juridical empiric was the method used in this study, it is a sociological research method or field research and it aims to review the prevailing provisions of law and in the society in effect. Furthermore, the result of the study shows there is existence of lack application of prevailing law and regulations of road construction towards the society's need and traditions in Sorong, West Papua. The failings were the failure of implementation of law and regulations stipulated by the government toward the society's need and circunstances that crucially accentuate the customary law to excute the procurement and settlement of communal land dispute of road construction in Sorong, West Papua.
\end{abstract}

Key Words: dispute settlement, communal land, road construction, Sorong Regency, West Papua.

\section{ABSTRAK}

Penelitian ini dilakukan untuk melihat bagimanakah penyelesaian sengketa tanah ulayat pada proyek pembangunan jalan di Kabupaten Sorong Papua Barat. Tujuan penelitian adalah untuk mengetahui dan memahami praktek pelaksanaan penyelesaian sengketa dan juga faktor penyebab terjadinya sengketa tanah ulayat pada proyek pembangunan jalan di Kabupaten Sorong Papua Barat. Metode penelitian yang digunakan dalam penelitian ini adalah yuridis empiris yaitu jenis penelitian sosiologis atau yang disebut dengan penelitian lapangan, yang mana penelitian ini mengkaji terkait ketentuan hukum yang sedang berlaku dan juga terjadi pada lingkungan masyarakat tersebut. Hasil penelitian 
ini menunjukkan bahwa terdapat kekurangan dalam penerapan peraturan perundang-undangan pelaksanaan pembangunan jalan yang berlaku terhadap kebiasaan dan kebutuhan masyarakat di Kabupaten Sorong Papua Barat. Kekurangan tersebut terkait tidak dapat berjalannya peraturanperaturan perundang-undangan yang telah ditetapkan oleh pemerintah dengan kondisi dan kebutuhan masyarakat yang masih mengutamakan hukum Adat setempat untuk melaksanakan pengadaan dan penyelesaian sengketa tanah ulayat pada proyek pembangunan jalan di Kabupaten Sorong Papua Barat.

Kata Kunci: Penyelesaian Sengketa, Tanah Ulayat, Pembangunan Jalan, Kabupaten Sorong, Papua Barat

\section{A. PENDAHULUAN}

Bagi kehidupan manusia tanah memiliki makna yang cukup lengkap, seperti dari sisi ekonomi tanah dapat digunakan sebagai sarana produksi untuk membangun kesejahteraan masyarakat setempat baik secara individu maupun kelompok. Secara administratif tanah dapat menjadi eksistensi dari sebuah negara untuk menentukan keberadaan Negara tersebut di bumi ini. Bahkan tanah tersebut dapat bermakna sakral dikarenakan setiap manusia pada akhir hidupnyanya akan kembali pada tanah. ${ }^{1}$ Oleh sebab itu setiap individu atau kelompok masyarakat yang memiliki tanah akan cenderung mempertahankan tanah yang dimiliki dengan berbagai cara jika hakhaknya dilanggar.

Pentingnya tanah bagi kehidupan manusia sebagai individu maupun suatu negara yang merupakan organisasi masyarakat tertinggi diatur secara, konstitusional, dalam, Undang-Undang, Dasar, 1945, pasal 33 ayat (3) bahwa "Bumi, air dan kekayaan alam yang terkandung di dalamnya dikuasai oleh negara dan digunakan sebesar-besarnya bagi kemakmuran rakyat". Berdasarkan Pasal 33 ayat (3) Undang-Undang Dasar 1945 inilah maka lahirlah Undang-Undang, Nomor, 5 Tahun 1960 tentang Peraturan, Dasar PokokPokok, Agraria, yang selanjutnya, lebih dikenal dengan, sebutan Undang-Undang, Pokok, Agraria (UUPA). Undang-Undang Nomor, 5 Tahun 1960 tentang Peraturan,

${ }^{1}$ Heru Nugroho.(2001). Menggugat Kekuasaan Negara, Surakarta: Muhammadiyah University Press, hlm. 23.
Dasar Pokok-Pokok, Agraria, ini bertujuan untuk :

1. Sebagai dasar penyusunan hukum agraria nasional yang berfungsi sebagai alat untuk membawa kemakmuran, kebahagiaan dan keadilan bagi negara dan rakyat terutama dalam rangka mewujudkan masyarakat adil dan makmur.

2. Sebagai dasar, untukmengadakankesatuan, serta kesederhanaan dalam hukum pertanahan.

3. Sebagaidasar,untukmemberikan,kepastian hukum, mengenai hak-hak atas tanah, bagi rakyat seluruhnya.

Salah satu hak yang dijamin oleh pemerinta ialah hak Ulayat, hal ini tergambarkan dalam pasal 3 Undang-undang Pokok Agraria yang menyatakan :

"Pelaksanaan hak-Ulayat dan hakhak yang serupa itu dari masyarakatmasyarakat hukum Adat, sepanjang menurut kenyataannya masih ada, harus sedemikian rupa sehingga sesuai dengan kepentingan nasional dan Negara, yang berdasarkan atas persatuan bangsa serta tidak boleh bertentangan dengan undangundang dan peraturan-peraturan lain yang lebih tinggi". ${ }^{2}$

Berdasarkan penjelasan pasal 3 UndangUndang Nomor, 5 Tahun 1960 tentang Peraturan, Dasar Pokok-Pokok, Agraria ,terkait berlakunya hak-hak Ulayat maupun hak-hak Adat lain yaitu: ${ }^{3}$

\footnotetext{
${ }^{2}$ Undang-Undang Nomor 5 Tahun 1960 tentang Peraturan Dasar Pokok-Pokok Agraria, Pasal 3.

${ }^{3}$ Winahyu Erwiningsih.(2009). Hak Menguasai Negara Atas Tanah, Yogyakarta: Total Media, hlm.4.
} 
1. Masih ada dalam masyarakat (masih merupakan kenyataan hidup).

2. Harus sedemikian rupa disesuaikan dengan kepentingan nasional dan negara.

3. Tidak boleh bertentangan dengan undangundang dan peraturan lain.

Belakangan ini Indonesia sedang melakukan pembangunan dibeberapa bagian yang tertinggal. Program pembangunan jalan tol, jalur kereta api, dan infrasturktur lainnya diharapkan dapat meningkatkan perekonomian masyarakat lokal dan juga meningkatkan taraf hidup masyarakat di wilayah-wilayah terpencil. Untuk menunjang kegiatan ini maka pemerintahpun menjadikan ini sebagai kebijakan dalam negeri untuk membangun dan mengembangkan insfrastruktur di seluruh wilayah Indonesia. ${ }^{4}$

Papua merupakan salah satu wilayah yang menjadi sasaran pembangunan dan pengembagan infrastruktur oleh pemerintah Indonesia. Papua yang disinyalir sebagai salah satu provinsi yang memiliki kekayaan alam yang luar biasa selama ini tidak dapat dikelola secara maksimal oleh masyarakat setempat dikarenakan keterbatasan akses dan fasilitas. ${ }^{5}$ Oleh karena itu pemerintahpun menjadikan papua sebagai salah satu pembangunan yang diharapkan akan meningkatkan ekonomi dan taraf hidup masyarakat setempat.

Pembangunan jalan antar desa, kabupaten/ kota dan juga provinsi di papua diharapkan akan dapat menunjang pertumbuhan masyarakat di papua. Dengan adanya akses penghubung maka akan memudahkan pendistribusian logistik dan kebutuhan hidup lainnya untuk memenuhi kehidupan masyarakat diwilayah-wilayah yang selama ini sulit dijangkau karena kurangnya akses dan fasilitas untuk menuju kesana.

\footnotetext{
${ }^{4}$ Jawa Pos, Strategi Pemerintah Dorong Pembangunan Infrastruktur Dalam Negeri, https://www.jawapos.com/ read/2017/12/15/175059/strategi-pemerintah-dorong-pembangunan-infrastruktur-dalam-negeri, diakses tanggal 18 Februari 2018

5 Media Indonesia, Keterbatasan Akses Jadi Masalah Wisata di Papua, http://mediaindonesia.com/read/detail/4181-keterbatasan-akses-jadi-masalah-wisata-di-papua, diakses tanggal 18 Februari 2018
}

Pembangunan Jalan Raya Trans Papua adalah salah satu proyek besar pemerintah untuk menghubungkan wilayah-wilayah yang berada di Papua. Dengan adanya proyek Trans Papua ini maka akan menghubungkan wilayah-wilayah yang berada di Papua dan Papua Barat sehingga akan dapat memudahkan masyarakat untuk berinteraksi antar desa hingga provinsi. Sembari pembangunan Trans Papua ini pemerintah juga terus meningkatkan pembangunan dan pengembangan daerah yang telah dapat diakses dikarenakan adanya proyek Trans Papua ini. ${ }^{6}$

Pembanguanan jalan antar desa terus dibangun dan dikembangkan mulai dari wilayah perkotaan hingga wilayah-wilayah yang selama ini belum pernah terjangkau. Sehingga banyak sekali proyek pembangunan yang dilakukan oleh pemerintah khususnya proyek pembangunan jalan-jalan di Papua yang menghubungkan antar desa satu dengan desa lainnya.

Pembangunan-pembangunan aksesakses jalan yang dilakukan oleh pemerintah tersebut tentunya melibatkan kontraktorkontraktor yang berada di daerah tersebut. Kontraktor-kontraktor tersebut bertugas untuk menyediakan jasa pengadaan barang dan jasa pembangunan terhadap program yang telah ditetapkan oleh pemerintah. Pelibatan kontraktor dalam proyek pembangunan ini diharapkan dapat menciptakan lapangan pekerjaan dan juga partisipasi masyarakat secara langsung dalam pembangunan dan pengembangan wilayah tersebut.

Penunjukan kontraktor sebagai pihak yang bertanggung jawab terhadap jasa pembangunan proyek tersebut biasa ditentukan melalui lelang yang diadakan oleh pemerintah. Pihak kontraktor yang memenangkan lelang tentu bertanggung jawab terhadap proyek pembangunan yang telah diberikan kepada kontraktor.

\footnotetext{
${ }^{6}$ Hendra Kusuma - detikFinance, Ada Jalan Trans Papua, Masyarakat Pedalaman Makin Mudah ke Kota https:// finance.detik.com/berita-ekonomi-bisnis/d-3519269/adajalan-trans-papua-masyarakat-pedalaman-makin-mudah-kekota, diakses tanggal 18 februari 2018
} 
Dengan rute, bentuk dan waktu yang telah disepakati bersama oleh pihak kontraktor dan pemerintah disaat para kontraktor mengkuti lelang tersebut.

Pembangunan yang dilakukan oleh para kontraktor-kontraktor biasanya akan melewati beberapa wilayah Adat yang dimiliki oleh masyarakat papua salah satunya ialah tanah Adat atau Ulayat yang dimiliki oleh sukusuku setempat. Pembangunan yang melewati wilayah-wilayah Adat atau Ulayat masyarakat papua ini biasanya akan mengalami kendala atau hambatan berupa adanya sengketa terhadap lahan proyek yang sedang dikerjakan oleh para kontraktor. Sengketa itu berawal dari adanya tuntutan dari masyarakat Adat yang meminta penggantian hak yang dimiliki oleh masyarakat Adat terhadap lahan yang akan digunakan untuk pembangunan tersebut. Jika tuntutan masyarakat Adat ini belum terpenuhi maka masyarakat Adat ini tidak menghendaki wilayah Adat atau lahan yang dimiliki digunakan untuk pembangunan.

Masyarakat Adat biasanya akan melakukan pemalangan atau pengerahan masa pada lokasi yang sedang dilakukan pembangunan dengan menyuarakan tuntutan terhadap hak masyarakat Adat kepada kontraktor yang sedang melakukan pembangunan di wilayah masyarakat tersebut. Apabila kontraktor tidak bersedia memberikan tuntutan yang diminta maka proyek pembangunan tersebut tidak boleh dilanjutkan. Sehingga dengan sangat terpaksa kontraktorpun harus menghentikan sementara proyek yang sedang dikerjakan sampai masyarakat tersebut mendapatkan haknya.

Tanah Ulayat ini sendiri merupakan hak. tertinggi terhadap tanah yang dimiliki oleh suatu kelompok persekutuan hukum desa atau suku untuk menjamin sebuah ketertiban dalam pemanfaatan/pendayagunaan tanah. Hak Ulayat adalah hak yang dimiliki oleh suatu persekutuan hukum desa atau suku dimana para warga masyarakat persekutuan hukum tersebut memiliki hak. untuk menguasai tanah, yang mana pelaksanaannya diatur oleh ketua persekutuan (kepala suku/ kepala desa yang bersangkutan)".?

Hak-hak masyarakat inilah kemudian yang menjadi tuntutan masyarakat Adat kepada kontraktor dikarenakan kontraktor telah melakukan pembangunan pada wilayah Ulayat yang dimiliki oleh masyarakat Adat tersebut, sehingga perlu adanya ganti rugi terhadap tanah tersebut. Permasalahan ini tentunya menimbulkan sengketa antara masyarakat Adat dan juga kontraktor sebagai pihak yang ditugaskan melaksanakan pembangunan di daerah tersebut. Sehingga program pembangunan yang dilaksanakan oleh kontraktor menjadi terhambat karena adanya pemalangan oleh masyarakat Adat setempat terhadap lokasi proyek yang sedang dikerjakan oleh para kontraktor.

Berdasarkan Undang-ndang nomor 2 Tahun 2012 Tentang Pengadaan Tanah Bagi Pembangunan Untuk Kepentingan Umum pada Pasal 1 Ayat 2 dikatakan bahwa "Pengadaan Tanah adalah kegiatan menyediakan tanah dengan cara memberi ganti kerugian yang layak dan adil kepada pihak yang berhak". Selanjutnya dalam Pasal 3 Undang-Undang yang sama dikatakan bahwa "Pihak yang Berhak adalah pihak yang menguasai atau memiliki objek pengadaan tanah". Dalam hal pihak yang berhak pada permasalahan ini ialah masyarakat adat yang tanahnya digunakan untuk pembangunan jalan di Kabupaten Papua Barat. Yang mana mereka menuntut untuk diberikan penggantian terhadap haknya oleh pihak yang berwenang dalam hal ini adalah pemerintah. Sebagaimana tertuang dalam pasal 6 UndangUndang Nomor 2 Tahun 2012 tersebut bahwa "Pengadaan Tanah untuk Kepentingan Umum diselenggarakan oleh Pemerintah".

Pada pelaksanaan proyek pembangunan seharusnya pihak-pihak terkait sudah menyelesaikan segala sesuatu yang berkaitan dengan pelaksanaan pembangunan tersebut. Salah satu yang sudah seharusnya diselesaikan

G.Kertasapoetra dan kawan-kawan.(1985). Hukum Tanah Jaminan Undang- Undang Pokok Agraria Bagi Keberhasilan Pendayagunaan Tanah, Jakarta: Bina aksara, hlm. 88 . 
oleh para pihak dalam permasalahan ini ialah terkait tanah yang akan digunakan untuk pembangunan jalan di Kabupaten Sorong sehingga salah satu pihak tidak merasa dirugikan dikemudian hari.

\section{B. PEMBAHASAN}

Kabupaten Sorong merupakan salah satu Kabupaten yang berada di Provinsi Papua Barat Indonesia, yang mana Ibu Kota dari Kabupaten Sorong ini terletak di Aimas. Kabupaten Sorong memiliki luas wilayah $17.970 \mathrm{Km}^{2}$. yang terdiri dari lautan seluas $9.214 \mathrm{Km}^{2}$ dan daratan seluas $8.756 \mathrm{Km}^{2}$. Kabupaten Sorong terletak diantara $130^{\circ}$ dan $132^{\circ} 55^{\prime}$ Bujur Timur serta $01^{\circ}$ dan $02^{\circ}$ Lintang Utara. Batas administrasi Kabupaten Sorong adalah sebagai berikut :

1. Sebelah Barat : Kota Sorong, Kabupaten Raja Ampat

2. Sebelah Timur: Kabupaten Manokwari dan Kabupaten Tambrauw

3. Sebelah Utara : Samudra Pasifik

4. SebelahSelatan:LautSeramdanKabupaten Sorong Selatan

Keadaan Topografi Kabupaten Sorong sangat bervariasi, mulai dari rawa, dataran rendah hingga pegunungan yang berada pada wilayah kabupaten sorong. Kabupaten Sorong memiliki wilayah $60 \%$ (persen) berupa daerah pegunungan dengan lerenglereng yang curam. Karakter wilayah seperti ini berada pada wilayah Kecamatan Makbon, Sausapor, Moraid dan juga pulau Salawati yang terdapat pada bagian tengah pulau. Sekitar 20\% (persen) berupa dataran rendah dan juga rawa yang tersebar pada wilayah bagian selatan sampai ke barat Kabupaten Sorong.

Kabupaten Sorong juga memiliki ketinggiam wilayah yang cukup bervariasi, yaiutu wilayah yang berada pada ketinggian di bawah 100 meter diatas permukaan laut (mdpl) pada umumnya berada pada wilayah kecamatan Seget Beraur dan sebagian Kecamatan Salawati bagian selatan. Sedangkan wilayah yang berada pada ketinggian 500 mdpl terletak pada
Kecamatan Aimas dan Salawati bagian tengah. Untuk ketinggian 500-2000 mdpl sebagian besar terletak pada Kecamatan Sausapor. Kabupaten Sorong umumnya beriklim tropis yang lembab dan panas. Suhu udara berkisar antara 25,5 derajat Celsius sampai dengan 30,7 derajat Celsius dengan kelembaban udara (RH) 84\% (persen). Curah hujan rata-rata $2.836,4$ milimeter pertahun dengan jumlah hari 107-185 turun hujan.

Sejak 2014 penduduk Kabupaten Sorong menunjukkan laju pertumbuhan yang sangat positif, pada 2014 jumlah penduduk pada Kabupaten Sorong berjumlah 78.698 yang mana terdiri dari 41.624 laki-laki dan 37.074 perempuan dan mengalami penaikan pada 2015 dengan total penduduk 80.695 yang terdiri dari 42.708 laki-laki dan 37.987 prempuan. Selanjutnya pada tahun 2016 jumlah penduduk di Kabupaten Sorong meningkat lagi menjadi 82.784 dengan jumlah 43.683 laki-laki dan 39.101 perempuan. Sedangkan pada 2017 jumlah Penduduk di Kabupaten Sorong mencapai 84.870 yang mana jumlah ini terbagi menjadi 44.705 laki-laki dan 40.165 perempuan. Sejak 2014 penduduk Kabupaten Sorong menunjukkan laju pertumbuhan yang sangat positif, pada 2014 jumlah penduduk pada Kabupaten Sorong berjumlah 78.698 yang mana terdiri dari 41.624 laki-laki dan 37.074 perempuan dan mengalami penaikan pada 2015 dengan total penduduk 80.695 yang terdiri dari 42.708 laki-laki dan 37.987 prempuan. Selanjutnya pada tahun 2016 jumlah penduduk di Kabupaten Sorong meningkat lagi menjadi 82.784 dengan jumlah 43.683 laki-laki dan 39.101 perempuan. Sedangkan pada 2017 jumlah Penduduk di Kabupaten Sorong mencapai 84.870 yang mana jumlah ini terbagi menjadi 44.705 laki-laki dan 40.165 perempuan.

Masyarakat Adat yang mendiami Kabupaten Sorong ialah Masyarakat Adat Moi. Mayarakat Adat Moi menguasai seluruh wilayah yang berada pada Kabupaten Sorong yang menyatakan tanah-tanah yang berada di Kabupaten Sorong adalah milik dari 
masyarakat Adat Moi. Tanah-tanah yang berada dalam wilayah masyarakat Adat Moi dalam pengelolaanya harus meminta izin kepada masyarakat adat Moi tersebut yang merupakan penguasa dari tanah-tanah yang berada di Kabupaten Sorong dikarenakan tanah yang mereka kuasai dan akan digunakan untuk keperluan lain harus sesuai dengan hukum Adat yang berlaku pada suku Moi.

Mayarakat Moi dalam memahami tanah ulayat yang dimiliki oleh mereka ialah bahwa tanah ulayat adalah tanah Adat yang penguasaannya berdasarkan atas keret (marga) yang dalam penggunaannya masih bersifat secara komunal oleh para keret yang berada dalam struktur masyarakat adat Suku Moi. Namun dalam hal kepemilikan maka harus berdasarkan atas keret atau marga masing-masing yang berada dalam struktur masyarakat Adat Moi. Hal ini terlihat dari adanya keberagaman marga yang menempati sebuah kampung yang dikuasai oleh salah satu marga masyarakat Adat Moi. Masyarakat Adat ini hidup berdampingan satu dan yang lainnya memanfaatkan hasil alam yang berada pada lingkungan mereka untuk memenuhi kebutuhan anak-anak dan keluarga. Namun untuk pelepasan atau peralihan hak atas tanah harus berdasarkan kepemilikan oleh keret yang memiliki tanah tersebut dan tidaklah berhak keret lain mengalihkan tanah tersebut meski mereka merupakan satu suku Moi. Sistem kepemilikan hak-hak ulayat yang dimilikioleh masyarakat Adat Moi ialah berdasarkan harta warisan atau hak yang diberikan secara turun-temurun.

Hak penguasaan tanah Adat yang dimiliki oleh masyarakat Moi yang dikenal dengan hak teges te moi yang berarti hak yang diturunkan secara turun temurun memiliki beberapa bentuk hak kepemilikan berdasarkan sejarah dari kepemilikan tanah terebut. Adapun kepemilikan terhadap tanah tersebut terbagi ke dalam lima hak teges te moi yaitu :

1. Hak Eges Fmun

Hak Eges Fmun merupakan hak milik yang dimilik oleh keret atau marga bedasarkan warisan dari nenek moyang mereka terhadap anak cucu mereka. Yang mendapatkan warisan dalam hak eges fmun ini ialah hanya anak laki-laki saja dari garis keturunan ayah. Hak eges fmun ini ialah hak asli dari kepemilikan tanah tersebut dari apa yang dimiliki oleh nenek moyang mereka terhadap tanah tersebut. Biasanya sang anak akan mendapatkan cerita dari orang tua mereka terhadap tanah yang dimiliki tersebut termasuk batas, sejarah dan juga nilai-nilai mistis-religius yang dimiliki oleh tanah tersebut sehingga mereka dapat mempertanggung jawabkan dan menjaga tanah tersebut kelak jika orang tua mereka sudah meninggal.

2. Hak Woti

Merupakan hak milik atas dikarenakan jasa yang sangat besar dari salah satu marga Moi kepada marga yang memiliki tanah tersebut. Hak woti pada zaman dahulu diberikan karena marga lain karena telah membantu marga yang memiliki hak tanah tersebut dalam mempertahankan keturunannya dalam sebuah perang besar yang dialami oleh suku Moi. Sehingga atas jasanya yang memiliki tanah tersebut mengajak marga yang telah membantu marga yang memiliki tanah ini untuk samasama memanfaatkan tanah yang dimiliki oleh marga telah berhasil diselamatkan dalam perang besar tersebut.

3. Hak subey

Hak subey adalah hak yang diberikan kepada saudara sepersusuan oleh keret pemiliktanahkepadakeretlainyangmenjadi saudara sepersusuannya. Kepemilikan hak subey ini merupakan hak pakai saja, yang mana berarti keret yang mendapatkan hak subey boleh menggunakan tanah tersebut namun tidak boleh mengalihkannya kepada pihak lain dikarenakan tidak adanya kewenangan hak milik yang dimiliki oleh saudara sepersusuan ini. Namun untuk bercocok tanam dan berburu tetaplah keret yang mendapatkan hak subey ini dapat menggunakannya sebagaimana margamarga lain.

4. Hak Su Kban 
HakSuKbanmerupakanhakpemberian tanah kepada anak perempuan sebagai tempat berladang atau melakukan aktifitas kesehariannya pada tanah tersebut seperti berladang atau tokok sagu. Hak Su Kban ini adalah hak milik bagi anak perempuan ini untukmenggunakan dan memanfaatkannya sesukahatinyaselamaanakperempuanyang memiliki hak su kban ini masih tinggal pada wilayah tersebut. Namun apabila anak tersebut tidak menetap pada tanah tersebut karena memutuskan untuk berpindah atau merantau maka tanah tersebut akan dikembalikan kepada pihak yang memiliki tanah tersebut. Selain itu apabila anak perempuan tersebut menikah maka hak su kban yang dimiliki oleh anak tersebut tidaklah berhak untuk dimiliki hak tersebut lagi.

5. Hak Somala

Hak Somala merupakanmerupakanhak penyerahanhakulayatkepadapihakluaratau margalaindariyangmemilikitanahtersebut. Penyerahan hak ulayat kepada marga lain dikarenakan karena marga tersebut merasa tidak nyaman untuk memiliki tanah tersebut sehingga akan menyerahkannya kepada marga lain untuk dimanfaatkan. Namun biasanya hak somala ini akan dilakukan bila marga lain tersebut juga menyerahkan hakmilikmerekauntukdimanfaatkanmarga tersebut. Singkatnya hak somala adalah hak akibatpertukarantanahyangdilakukanantar marga untuk memaksimalkan pengolahan tanah sesuai dengan kemampuan masingmasing marga tersebut.

Kelima hak di atas merupakan hak dasar penguasaan atas tanah ulayat yang dimiliki oleh suku Moi. Sampai sekarang hak tersebut masih dijalankan oleh masyarakat suku Moi untuk menjaga dan memanfaatkan tanah ulayat tersebut baik secara bersamaan atau secara individu berdasarkan kepemilikan sesuai marga atau keretnya masing-masing. Hal ini dilakukan untuk menghindari perpecahan antar marga yang dimiliki oleh suku Moi agar tidak lagi terjadi peperangan seperti dahulu.
Secara praktis tanah-tanah dan hutan di Papua masih memiliki hubungan yang erat dengan masyarakat setempat. Selain itu, masyarakat Adat Moi juga memiliki system pengelolaan sumber daya alam sendiri yang diwariskan secaran turun temurun untuk mengolah dan pemanfaatan yang berkelanjutan ganhkan telah menjadi bagian dari khasanah sosiokultur masyarakat Moi. System yang telah diwariskan secara turuntemurun tersebut saat ini menjadi sebuah kebiasaan atau atauran Adat yang dewasa ini disebut hukum Adat. Aturan atau hukum Adat inilah yang menjadi sumber dari berbagai aturan dalam mengelola sumber daya alam di suku Moi yang berdasarkan nilai-nilai adat istiadat dan budaya yang dimiliki oleh masyarakat Moi.

Tanah-tanah yang berada pada Kabupaten Sorong juga masih banyak yang dipercayai oleh suku Moi memiliki nilai magis-religius yang harus dijaga oleh marga-marga bahkan suku Moi yang berada pada daerah tersebut. Tempat-tempat magis-religius ini tidaklah boleh diganggu keberadaannya karena dipercaya disanalah bermukim para leluhur dan nenek moyang mereka yang telah memberikan mereka tanah-tanah dan kehidupan sampai saat ini. Bagi masyarakat Adat suku Moi tanah-tanah atau wilayah ini jika diusik atau di ganggu keberadaannya maka akan mendatangkan bahaya bagi orang-orang yang mencoba mengusik tempat tersebut. Bahkan sampai sekarang dalam kalangan masyarakat Moi kita akan sering mendengar cerita aneh yang berkaitan dengan tanah tersebut seperti orang yang mencoba mengusik tanah tersebut maka ia akan mati atau tersesat dalam wilayah tersebut hingga mati. Hal-hal seperti ini masih sering dan sangat kental sekali keberadaanya dalam masyarakat Moi.

Tanah-tanah yang biasa memiliki kekuatan magis bagi masyarakat suku Moi ialah tanahtanah yang terdapat pohom-pohon besar maupun batu-batu besar. Selain pohon dan batu-batu besar tanah yang memiliki keunikan tersendiri akan dianggap keramat juga oleh 
masyarakat Moi. Seperti adanya sumber air panas pada pinggiran Kabupaten Sorong tepatnya pada wilayah Kelalin. Wilayah Kelalin ini dianggap sebagai tanah yang sangat keramat bahkan tidak sembarang orang boleh masuk ketempat ini. Sehingga tempattempat seperti ini akan menjadi tempat yang sangat disakralkan oleh masyarakat Adat Moi. Selain lokasi-lokasi di atas ada juga lokasi-lokasi lain yang dianggap memiliki nilai magis-religius yang lain tergantung dari wilayah dan kepercayaan marga atau keret yang menguasai wilayah tersebut. Termasuk kepercayaan terhadap adanya benda-benda pusaka atau adat yang tersembunyi di wilayah mereka yang tidak bias dijelaskan bentuk dan juga lokasinya kepada sembarang orang. Hanyalah para tetua-tetua marga yang mengetahui letak dan bentuk bendabenda tersebut yang dianggap sebagai benda peninggalan leluhur masyarakat Moi.

Pengaturan terhadap tanah-tanah ulayat yang dimiliki oleh masyarakat adat Moi ini akan diberikan kepada Dewan adat yang merupakan tokoh yang berada pada masyarakat Adat Moi. Dewan Adat Masyarakat Moi diangkat karena telah selesai pendidikan khusus yang berada pada masyarakat Moi. Dewan merupakan tokoh yang paham terhadap hukum adat dan juga warisan-warisan nenek moyang suku Moi terhadap masyrakat Moi yang telah terbagi kepada keret-keret yang berada pada masyarakat Moi saat ini. Selain Dewan Adat ada juga Lembaga Masyarakat Adat Moi yang merupakan lembaga yang menaungi seluruh masyarakat Moi beserta dewandewan Adat yang tersebar ditiap keret-keret atau wilayah-wilayah yang tersebar di kepala burung Papua.

Lembaga Masyarakat Adat Malamoi adalah lembaga yang menaungi berbagai persoalan Adat yang berkaitan dengan suku Moi baik yang berada dalam masyarakat Adat itu sendiri maupun yang berkaitan juga dengan pihak luar dari suku Moi. Karena seiring berjalannya waktu masyarakat Moi menyadari bahwa aka nada perubahan dan pergeseran budaya pada tanah mereka sehingga perlulah didirikan sebuah lembaga resmi untuk menjaga adat-istiadat dab budaya Moi agar tidak hilang akibat pembangunan dan perubahan social pada tanah Moi. Hal inilah yang kemudian mengakibatkan dibentuknya sebuah lembaga organisasi modern yang dapat mewadahi seluruh kepentingan masyarakat Moi yang berkaitan dengan hukum dan hak-hak adat yang dimiliki oleh suku Moi. Kehadiran Lembaga Masyarakat Adat Malamoi ini telah diterima oleh masyarakat yang berada pada Kota dan juga Kabupaten Sorong.

Lembaga Masyarakat Adat Malamoi berdiri pada tanggal 25 maret 1998 oleh para relawan pribumi yang merasa khawatir terhadap kondisi masyarakat adat Moi sebagai oenduduk pribumi. Status dari lembaga adat malamoi ini dilegitimasi melalui siding adat suku Moi pada tahun 1999 dengan tujuan untuk memperjuangkan hak, menyalurkan aspirasi, dan memberdayakan masyarakat hukum adat suku Moi di daerah kepala burung agar masyarakat Adat suku Moi tetap eksis di tengah masyarakat majemuk modern. Selain itu keberadaan Lembaga adat Malamoi diharapkan menjadi jembatan penghubung antara masyarakat Adat suku Moi dan Masyarakat Adat suku yang lainnya serta penghubung dengan pemerintahan resmi.

Tugas pokok dari Lembaga Adat Malamoi ialah sebagai berikut :

1. Menegakkan kewibawaan hokum Adat

2. Menata hak-hak batas tanah-tanah dari masing-masing keret

3. Menyelenggarakan peradilan hokum Adat

4. Menegakkan HAM masyarakat Adat

5. Menertibkanpengelolaansumberdayaalam di seluruh wilayah hukum Adat wilayah Malamoi dan kesejahteraan masyarakat Moi khususnya dan masyarakat Sorong umumnya

Adapun dasar pembentukan Lembaga Masyarakat Adat Malamoi ialah sebagaaai berikut :

1. Deklarasi Universal PBB Tahun 1948 Tentang Hak Asasi Manusia 
2. Deklarasi PBB tentang Hak-Hak Masyarakat Adat (UNDRIP)

3. Undang-undang RI Nomor 21 tahun 2001 tentangOtonomiKhususBagiPrvinsiPapua.

4. Keputusan Sabalo (Konfrensi Besar Masyarakat Adat Suku Moi di BLKI Kota Sorong) Nomor 03/KPTS/SABALO/2013 tentang Anggaran Dasar dan Anggaran Rumah Tangga Organisasi MasyarakatAdat Suku Moi tahun 2013.

5. Keputusan Sabalo (Konfrensi Besar Masyarakat Adat Suku Moi di BLKI Kota Sorong) Nomor 04/KPTS/SABALO/2013 tentang Program Kerja Lembaga Masyarakat Adat Malamoi Periode 20132018.

6. Keputusan Sabalo (Konfrensi Besar Masyarakat Adat Suku Moi di BLKI Kota Sorong) Nomor 06/KPTS/SABALO/2013 tentang Ketua Lembaga Masyarakat Adat Malamoi Periode 2013-2018.

7. Akta Notaris Aritha Hersila, S.H., M.Kn. Nomor 73 tanggal 8 November 2013.

Berdirinya Lembaga Masyarakat adat Malamoi ini tentunya diharapkan akan berdampak positif bagi masyarakat di wilayah Sorong khususnya masyarakat Adat Moi sehingga dapat melindungi budaya dan Adat dari suku Moi.

Proyek pembangunan jalan di wilayah Papua dan Papua Barat diharapkan dapat memberikan dampak positif pada wilayah tersebut. Proyek pembangunan jalan ini diharapkan dapat memberikan kemudahan kepada masyarakat sekitar untuk melakukan kegiatan bersosial dengan kelompok masyarakat lain yang berada di wilayah tersebut. Dengan adanya kemudahamn akses maka masyrakat sekitar akan lebih mudah menjangkau wilayah-wilayah yang sebelumnya belum pernah terjangkau.

Hal ini tidak terlepas dari kondisi wilayah Papua Barat yang mana wilayah ini masih sangat banyak lokasi-lokasi yang belum terjamah oleh manusia modern. Pada beberapa wilayah di wilayah Papua Barat atau Kabupaten Sorong tersebut hanyalah bermukim penduduk lokal yang hanya berinteraksi dengan sesama penghuni lokal daerah tersebut saja. Sesekali ada masyarakat desa yang terkadang mencari nafkah dengan berburu pada hutan yang berada di wilayah Kabupaten Sorong yang kemudian mempertemukan masyarakat Adat ini dengan kelompok lain yang bersal dari kampung lain sehingga terciptalah komunikasi diantara mereka mereka. Namun ada juga masyarakat tersebut yang terkadang turun ke kota untuk mendapatkan beberapa kebutuhan yang tidak bisa mereka dapatkan pada wilayah hutan sehinggalah tercipta interaksi antara masyarakat pedalaman ini dengan masyarakat modern di pusat kota Kabupaten Sorong.

Namun untuk bisa sampai wilayah kota tentunya masyarakat pedalaman yang berada di wilayah Papua Barat dan Kabupaten Sorong membutuhkan waktu dan perjuangan yang cukup sulit. Medan yang harus dilalui kadang menuntut mereka untuk berjalan dengan jarak tempuh yang sangat jauh. Selain harus berjalan dengan medan tempuh yang sangat jauh masyarakat pedalaman ini juga harus melewati sungai-sungai besar yang bila musim hujan arus pada sungai ini akan sangat deras sehingga akan menghambat masyarakat tersebut mencapai tujuan mereka. Pada beberapa wilayah sudah bisa dimasuki oleh kendaraan-kendaraan yang berasal dari kota. Namun hanya kendaraan-kendaraan khusus saja yang mampu menembus sampai pada wilayah tersebut dikarenakan medan yang cukup berat dan harus melewati lumpus dan juga sungai yang cukup deras arusnya. Untuk menggunakan transport tersebutpun akan cukup memakan biaya yang besar, sehingga tidak memungkinkan sebagian masyrakat untuk dapat menggunakan kendaraan tersebut.

Selain alasan-alasan tersebut tentunya ada beberapa alasan dan pertimbangan lain oleh pemerintah daerah maupun pusat yang menjadikan kebijakan pembangunan jalan dan infrastruktur di Papua Barat dan Kabupaten Sorong perlu untuk dilakukan. Sehingga dapat memberikan kemudahan bagi masyarakat di wilayah Papua Barat 
dan Kabupaten Sorong dalam mendapatkan kesejahteraan sosial di Indonesia.

Pembangunan ini tentunya melibatkan beberapa pihak baik pemerintah sebagai pihak penyedia jasa pembangunan, kontraktor sebagai pihak yang melakukan pembangunan dan juga masyarakat Adat setempat yang berada pada lingkungan pembangunan tersebut yang juga sebagai pemilik lahan yang akan digunakan dalam pembangunan jalan. Dalam proses pembanguna ini ketiga pihak tersebut akan bekerjasama agar terciptanya pembangunan yang baik untuk berbagai pihak sehingga tidak menimbulkan problem atau sengketa dalam proses pelaksanaannya maupun setelah proyek pembangunan itu selesai.

Namun dalam pelaksanaannya di lapangan ternyata terdapat sengketa terkait proses pembangunan jalan di Papua Barat ini khususnya di wilayah Kabupaten Sorong. Sengketa itu terkait tanah ulayat yang digunakan untuk lahan proyek pembangunan jalan di Papua Barat. Sengketa ini terjadi antara kontraktor sebagai pihak yang melaksanakan pembangunan jalan tersebut dan juga masyarakat Adat yang memiliki wilayah yang digunakan untuk proses pembangunan jalan tersebut. Ada beberapa faktor yang kemudian menjadi sumber dari adanya sengketa tanah ulayat antara kontraktor dan juga masyarakat Adat. Adapun faktor-faktor penyebab terjadinya sengketa antara kontraktor dan masyarakat adat ialah sebagai berikut :

\section{Faktor Tidak Adanya Pembebasan La- han Oleh Penyedia Jasa Pembangunan Jalan}

Berdasarkan Undang-ndang nomor 2 Tahun 2012 Tentang Pengadaan Tanah Bagi PembangunanUntukKepentinganUmumpada Pasal 1 Ayat 2 dikatakan bahwa "Pengadaan Tanah adalah kegiatan menyediakan tanah dengan cara memberi ganti kerugian yang layak dan adil kepada pihak yang berhak". Selanjutnya dalam Pasal 3 Undang-Undang yang sama dikatakan bahwa "Pihak yang Berhak adalah pihak yang menguasai atau memiliki objek pengadaan tanah". Dalam hal pihak yang berhak pada permasalahan ini ialah masyarakat adat yang tanahnya digunakan untuk pembangunan jalan di Kabupaten Sorong Papua Barat. Sedangkan pihak yang berkewajiban untuk malaksanakan ganti rugi terhadap tanah yang akan digunakan untuk proyek pembangunan tersebut ialah pemerintah. Sebagaimana tertuang dalam pasal 6 Undang-Undang Nomor 2 Tahun 2012 tersebut bahwa "Pengadaan Tanah untuk Kepentingan Umum diselenggarakan oleh Pemerintah". Pemerintah tentunya harus menjamin tersedianya dana untuk kepentingan pengadaan lahan proyek pembangunan jalan ini sebagaimana yang tertuang dalam Pasal 4 ayat (2) Undang-Undang Nomor 2 Tahun 2012 menyatakan bahwa "Pemerintah dan/atau Pemerintah Daerah menjamin tersedianya pendanaan untuk Kepentingan Umum".

Namun dalam praktek pelaksanaan proyek pembangunan jalan di Papua Barat sebagai mana yang diterangkan oleh Pejabat Pembuat Komitman Bina Marga Balai Pelaksanaan Jalan Nasional bahwa peraturan-peratruran tersebut tidaklah dapat berjalan dengan efektif untuk wilayah Papua dan Papua Barat. Pembebasan hak ulayat yang seharusnya menjadi kewenangan oleh pemerintah untuk wilayah Papua Barat akan dibebankan kepada kontraktor yang memenangkan lelang pembangunan jalan tersebut.

Pembebanan pembebasan hak ulayat yang diberikan kepada kontraktor merupakan hal yang sudah menjadi tanggung jawab tak tertulis yang harus dilaksanakan oleh kontraktor. Pembebanan pembebasan hak ulayat kepada kontraktor ini diketahui oleh pemerintah dan juga Bina Marga Balai Pelaksanaan Jalan Nasional dan Pejabat Pembuat Komitmen Bina Marga Balai Pelaksanaan Jalan Nasional yang berhubungan langsung dengan kontraktor terkait kontrak pelaksanaan pembangunan jalan tersebut.

Adapun isi kontrak tersebut secara garis besar berisi tentang Ruang lingkup pekerjaan,

\footnotetext{
${ }^{8}$ Uu no 2 tahun 2012
} 
nilai kontrak dan pembayaran terhadap pengadaan barang dan jasa kontraktor, Pelaksanaan, Penyelesaian, Adendum dan Pemutusan Kontrak, Pelaksanaan Pekerjaan, Pengendalian Waktu, Penyelesaian Kontrak, Keterlambatan Pelaksanaan Pekerjaan dan Kontrak Kritis. Dalam kontrak tersebut tentunya tidak dituliskan bahwa pembebanan pembebasan hak ulayat akan diberikan kepada mereka. Sebagai mana yang sudah dituliskan diatas bahwa pembebanan pembebasan hak ulayat tersebut akan dibebankan kepada kontraktor yang memenangkan lelang tersebut. Peraturan atau perjanjian ini tidaklah tertulis namun sudah menjadi kewajiban kontraktor yang memenangkan lelang pembangunan jalan tersebut.

Berdasarkan wawancara dengan Pejabat Pembuat Komitmen Bina Marga Balai Pelaksanaan Jalan Nasional, bahwa pembebanan pembebasan hak ulayat kepada kontraktor ini dikarenakan pada proyek pembangunan jalan yang dilakukan oleh pemerintah tersebut tidaklah memiliki anggaran untuk pembebasan hak ulayat kepada masyarakat setempat. Dalam Daftar Isian Pelaksanaan Anggaran (disingkat DIPA) yang menjadi dasar anggaran pelaksanaan proyek pembangunan jalan tersebut, tidaklah tercantum anggaran terkait pembebasan hak ulayat yang dimiliki oleh masyarakat Adat. Dalam DIPA tersebut hanya berisi anggaran yang akan difungsikan untuk pelaksanaan konstruksi atau fisik dari proyek tersebut saja.

Pengajuan terkait anggaran pembebasan hak ulayat tersebut sebenarnya telah disusun oleh pengguna anggaran dalam hal ini Bina Marga Balai Pelaksanaan Jalan Nasional sebagai pejabat pemegang kewenangan penggunaan anggaran. Namun anggaran tersebut tidak pernah diberikan oleh pusat, hanya anggaran terhadap fisik pembangunan saja yang diberikan oleh pusat kepada Bina Marga Balai Pelaksanaan Jalan Nasional. Sehingga hal inilah yang menjadikan kebijakan bahawa pelaksanaan pembebasan hak ulayat tersebut akan dimasukkan dalam anggaran fisik pembangunan tersebut yang tentunya akan dilakukan oleh kontraktor sebagai pihak yang memenangkan lelang tersebut.

Ketentuan inilah yang dikemudian hari dalam pelaksanaan proyek pembangunan jalan tersebut menjadi masalah sengketa antara pihak masyarakat Adat yang memiliki lahan yang digunakan untuk pembangunan jalan dan juga kontraktor sebagai pelaksana pembangunan jalan. Permasalahan ini dikarenakan kontraktor harus benar-benar bijak dalam penggunaan anggaran tersebut karena alokasi dana yang seharusnya hanya untuk fisik pembangunan tersebut harus dibagi lagi untuk pembebasan hak ulayat masyarakat Adat yang memiliki lahan yang akan digunakan tersebut.

Adakalanya tuntutan warga tersebut terlalu besar sehingga anggaran yang diterima kontraktor tidaklah cukup untuk pembebasan hak ulayat dan juga untuk fisik pembangunan proyek yang dilakukan oleh mereka. Sehingga tuntutan itu ditolak oleh kontraktor yang berujung pada pemalangan proyek tersebut oleh masyarakat sehingga kontraktor tidak bisa melanjutkan pekerjaan mereka. Disisi lain kontraktor dituntut untuk segera menyelesaikan proyek tersebut dikarenakan kontrak tersebut terus berjalan dengan batas waktu yang sudah ditentukan di dalam kontrak yang telah disepakati bersama antara pihak penyedia jasa yaitu Bina Marga Balai Pelaksanaan Jalan Nasional dan juga kontraktor saat memenangkan lelang dan menandatangani kontrak kerjasama tersebut.

\section{Faktor Penundaan Pembayaran Lahan Pembangunan Jalan Oleh Kontraktor}

Dalam pembayaran ganti rugi yang dilakukan oleh kontraktor kepada masyarakat adakalanya akan dilakukan secara kontan diawal sebelum proses pembangunan dilakukan. Namun kadang ada juga kesepakatan oleh kontraktor dan masyarakatn Adat bahwa pembayarannya akan dilakukan secara bertahap atau dicicil selama proses pembangunan berjalan. Pembayaran yang dilakukan secara bertahap ini akan dilunasi 
kepada masyarakat oleh kontraktor sebelum proses pembangunan tersebut selesai. Tentunya proses pembayaran tersebut ditentukan juga waktu pembayarannya secara bersama-sama oleh masyarakat dan juga kontraktor. Misalkan proyek pembangunan akan dilaksanakan selama 4 bulan dan kesepakatan bersama diantara masyarakat adat dan kontraktor akan dibayar secara 4 tahap maka pembayarannya dilakukan pertiap 30 hari atau sebulan dari waktu pembayaran pertama.

Kepastian waktu ini sangat dibutuhkan oleh masyarakat dikarenakan masyarakat adat biasanya akan menagih langsung kepada kontraktor dilokasi pembangunan tersebut dengan sistem transaksi cash. Sehingga kontraktor juga harus menyiapkan dan mencairkan dana tersebut dari bank yang kemudian akan diberikan kepada masyarakat Adat yang memiliki hak pada tanah tersebut. Kepastian waktu ini juga menjadi sangat penting terhadap masyarakat Adat yang memiliki hak tersebut namun masyarakat itu sudah tidak tinggal pada daerah tersebut atau merantau. Namun masyarakat tersebut masih memiliki hak pada tanah tersebut, sehingga masyarakat Adat tersebut akan kembali dan ikut menagih haknya kepada kontraktor sesuai jadwal yang ditentukan bersama dengan kontraktor.

Dalam proses pembayaran tersebut, tak jarang ada beberapa kontraktor yang akan mengalami kendala dalam pembayaran tuntutan yang diminta oleh masyrakat Adat. Kendala-kendala tersebut biasa terjadi karena beberapa hal seperti faktor alam, kurangnya koordinasi antara pekerja di lapangan dan di kantor, hingga faktor-faktor pekerjaan lainnya. Yang mengakibatkan kontraktor telat membayar kepada masyarakat sebagaimana yang telah disepakati bersama antara masyarakat dan juga pihak kontraktor.

Sebagaimana wawancara yang telah dilakukan dengan salah satu kontraktor yang melaksanakan pembangunan di Kabupaten Sorong. Bahwasanya dijelaskan kontrak yang disepakati dengan pihak penyedia jasa ialah pembayaran pertermin. Dalam kontrak tersebut pihak penyedia jasa akan memberikan dana kepada kontraktor melalui sistem pembayaran pertermin sesuai dengan persentase progress pekerjaan yang telah dilakukan oleh kontraktor. Apabila pekerjaan belum memenuhi target yang telah disepakati bersama antara pihak penyedia jasa dan kontraktor maka dana untuk progres selanjutnya tidak bisa diberikan oleh penyedia jasa kepada kontraktor sampai kontraktor memenuhi target yang telah disepakati sesuai dalam kontrak. Sehingga akan menghambat kontraktor untuk melakukan pembayaran kepada masyarakat Adat sesuai dengan jadwal yang telah disepakati antara kontraktor dan masyarakat Adat.

\section{Faktor Masyarakat Adat}

\section{a. Batas Hak Ulayat}

Batas wilayah hak ulayat yang dimiliki oleh masyarakat Adat sebenarnya sudah memiliki batas-batas yang jelas antara satu dan yang lainnya. Batas-batas hak ulayat yangdimilikiolehmasyarakatAdatbiasanya ditandai dengan bukit, gunung, lembah, dan sungai. Yang mana kesemua batas-batas wilayah ulayat itu sudah ditentukan dari nenek moyang mereka hingga mas kini. Beradasarkan wawancara dengan salah satu dewan Adat masyarakat Moi bahwa batasbatas tersebut sampai saat ini masih berlaku. Namunmungkinadabeberapawilayahyang bentukdanbatas-batasnyasudahmengalami perubahan akibat kondisi alam. Akan tetapi batas-batas tersebut masih bisa dilacak oleh masyarakatadatdenganmetode-metodedan juga pembuktian-pembuktian khusus yang dimiliki oleh masyarakat Adat tersebut.

Sengketa terkait batas wilayah ulayat antara kontraktor dan juga masyarakat Adat biasanya antara lain bermula saat kontraktor yang mencoba memasuki wilayah ulayat yang kan digunakan untuk pembangunan jalan mencoba berinteraksi dengan masyarakat ulayat yang berada pada wilayah tersebut untuk mensosialisasikan 
terkait pembangunan jalan dan juga terkait perizinan serta pembebasan hak ulayat yang akan digunakan untuk pembangunan jalan oleh kontraktor. Dari sini kontraktor akan diarahkan dengan tokoh kampung yang berada pada wilayah tersebut untuk membicarakan terkait penggunaan hak ulayat yang akan digunakan untuk pembangunanjalanolehkontraktortersebut.

Di tengah pelaksanaan pembangunan yang telah dilakukan oleh para kontraktor terkadang akan datang masyarakat Adat lainnya yang berasal dari keret atau marga lain yang mempertanyakan terkait pembangunan tersebut. Kemudian masyarakattersebutakanmengklaimbahwa tanahtersebutadalahmilikmerekabukanlah milik marga yang telah dilaksanakan ganti rugi oleh kontraktor. Tanah-tanah yang diklaim sebagai pemilikan oleh keret ini biasanyatidaklahsemuawilayah,melainkan hanyabeberapawilayahsajayangdigunakan oleh kontraktor untuk pembangunan jalan tersebut.Yangmanawilayahyangdigunakan adalah wilayah-wilayah yang berbatasan dengan wilayahkeretatau marga lain namun tidakdisampaikanolehkeretyangmenerima uang dari kontraktor.

Karena tidak terima tanah ulayat masyarakat Adat keret ini digunakan tanpa seizin dan pengetahuan masyarakat tersebut maka dimulailah pemalangan jalan oleh keret tersebut sehingga tidak bisa berjalanlah proyek pembangunan jalan tersebut. Pihak kontraktorpun yang telah merasa mengeluarkan uang terkait ganti rugi terhadap hak ulayat tersebut merasa sangat dirugikan oleh kejadian tersebutdikarenakanuangyang dikeluarkan telah diterima oleh masyarakat Adat dan mereka juga dikejar waktu untuk segera menyelesaikan proyek pembangunan jalan tersebut jika tidak tepat waktu mereka akan terkena denda.

Kedua pihak terkadang tidak ada yang saling mengalah, kontarktorpun tak mau untuk mengganti rugi dua kali di loakasi yang sama dan juga masyarakat adat yang merasa mereka perlu mendapatkan hak mereka terkait penggunaan lahan yang akan digunakan untuk pembangunan jalan tersebut.Sehinggapermasalahaninimenjadi semakin meruncing diantara kedua belah pihaktakjarangmasyarakatakanmenyerang kontraktor dengan senjata tajam jika kontraktornekatmeneruskanpembangunan jalandiwilayahmerekakarenamenganggap mereka tidak dihargai sama sekali. Kontraktorpun terkadang akan melibatkan aparat keamanan untuk membantu mereka meneruskan pembangunan tersebut dengan dilakukaknnya pressing terhadap masyarakat adat yang mencoba menghalangi proses pembangunan jalan tersebut. Tentunya hal ini menjadi permasalahan yang rumit yang harus segera dicarikan jalan keluarnya, sehingga tidak sampaimemakankorbanjiwadiantarakedua belah pihak.

b. Tidak Meratanya Pembagian Uang Hasil Pembayaran Hak Ulayat Yang Dilakukan oleh Kontraktor

Pelaksanaanpenggantiangantirugioleh kontraktor kepada masayarakat Adat yang berhak biasanya akan diserahkan kepada kepala keretatau pihak yang dituakan dalam keret tersebut. Hal ini dilakukan untuk menghormatitokohkerettersebutyangmana juga akan memimpin pelaksanaan upacara Adat dan lainnya terkait penggunaan hak ulayat tersebut. Kepala keret juga dipercaya oleh kontraktor untuk membagikan kepada keluarga lain yang memiliki hak terhadap tanah tersebut. Penyerahan kepada kepala keret ini dikarenakan keterbatasan kontraktor dalam menemukan pihak-pihak yang berhak dalam keluarga tersebut, yang mana kemudian akan diberikan haknya masing-masing. Oleh sebab itu terkait pembagian hak-hak masyarakat Adat tersebut sepenuhnya akan diwakilkan oleh kepala keret.

Dengan diberikannya uang tersebut kepada kepala keret sembari dilaksanakan acara Adat untuk penggunaan tanah ulayat 
tersebut maka selesailah tanggung jawab kontraktor terhadap masyarakat Adat tersebut. Selanjutnya proses pembangunan jalan akan segera dilaksanakan oleh kontraktor sesuai dengan perencanaan. Namun dalam pelaksanaan pembangunan tersebutpun masih terjadi permasalahan yang berasal dari masyarakat Adat itu sendiri juga yang menuntut bahwa hak mereka tidak dipenuhi atau belum adanya penggantian terhadap hak yang dimiliki oleh mereka terhadap tanah ulayat tersebut. Setelah didiskusikan ternyata masyarakat tersebut juga adalah masyarakat sah atau yang bermarga sama dengan pihak keret yang menerima uang ganti rugi dari kontraktor. Sehingga kontraktorpun enggan memberikan lagi uang ganti rugi tersebut kepada masyarakat yang menuntut haknya tersebut, hingga akhirnya masyarakat tersebut melakukan pemalangan jalan yang sedang dilakukan pembangunan oleh kontraktor tersebut sehingga kontraktor tersebuttidakbisamelakukanpembangunan jalan yang telah mereka lakukan.

Kasus seperti ini biasanya terjadi karena adanya keluarga dari keret tersebut yang tinggal jauh dari lingkungan keretnya. Sehingga tokoh keret tersebutpun susah untuk menghubungi keluarga tersebut untuk memberikan hak keluarga tersebut. Alhasil uang yang harusnya diberikan kepada keluarga yang jauh tersebut akan dibagi lagi terhadap keluarga yang berada disekitaran wilayah tersebut atau wilayah yang bisa dijangkau oleh kepala keret untuk memberikan informasi terkait pembagian uang ganti rugi yang diberikan oleh kontraktor. Pembagian yang tidak merata ini tentunya akan menjadi sebuah masalah juga baik didalam keret tersebut hingga terbawa pada kontraktor yang sedang melakukan pembangunan jalan. Yang berujung pada pemalangan jalan oleh masyarakat Adat sehingga kontraktor tidak bisa melaksanakan pembangunan jalan. Di sisi lain kontraktorpun menuntut kepada masyarakat Adat untuk membuka palang tersebut dikarenakan kontraktor telah melaksanakan kewajiban mereka sebagaimana mestinya.

SepertiyangdinyatakandalamUndangundang nomor 2 Tahun 2012 Tentang PengadaanTanahBagiPembangunanUntuk Kepentingan Umum pada Pasal 1 Ayat 2 dikatakan bahwa "Pengadaan Tanah adalah kegiatan menyediakan tanah dengan cara memberi ganti kerugian yang layak dan adil kepada pihak yang berhak". Selanjutnya dalam Pasal 3 Undang-Undang yang sama dikatakan bahwa "Pihak yang Berhak adalah pihak yang menguasai atau memiliki objek pengadaan tanah". Dalam hal pihak yang berhak pada permasalahan ini ialah masyarakat adat yang tanahnya digunakan untuk pembangunan jalan di Kabupaten Papua Barat. Selanjutnya tertuang dalam pasal 6 Undang-Undang Nomor 2 Tahun 2012 tersebut bahwa "Pengadaan Tanah untuk KepentinganUmum diselenggarakan oleh Pemerintah".

Sebagaimanayangtertuang dalampasal 6 Undang-Undang Nomor 2 Tahun 2012 tersebut bahwa "Pengadaan Tanah untuk Kepentingan Umum diselenggarakan oleh Pemerintah". Namun dalam praktek di lapangan pengadaan tanah yang harusnya menjadi tanggung jawab pemerintah dibebankan kepada kontraktor yang seharusnya hanyalah sebagai pelaksana pekerjaan saja. Di sisi lain pengadaan tanah yang dilakukan oleh kontraktor tersebutpun tidak memiliki payung hukum yang jelas. Di dalam kontrak tidaklah disebutkan terkait pelaksanaan pengadaan tanah yang dilakukan oleh kontraktor. Namun dalam pelaksanaan pekerjaan pengadaan tanah merupakan kewajiban mereka yang harus mereka lakukan juga selain membangun infrastruktur yang tertera dalam kontrak kesepakatan dengan pemerintah.

Hal ini tentu akan sangat memberatkan kontraktor dikarenakan kontraktor yang melaksanakan pekerjaan ini terbebankan dengan kewajiban yang seharusnya bukan menjadi tanggung jawab mereka. Namun 
jika mereka menolak pastinya proyek tersebut tidaklah akan mereka dapatkan sehingga pastinya akan mengancam keberlangsungan perusahaan tersebut. Tentunya kesepakatan ini akan sangat melemahkan posisi dari pihak kontraktor dikarenakan tidak adanya kontrak yang menjelaskan terkait pekerjaan mereka di lapangan. Selain itu untuk tanggung jawab apabila terjadi sengketa dan juga tuntutan dari masyarakatjuga akan diselesaikan oleh kontraktor.

Untukmengatasipermasalahaninimaka para kontraktor yang sedang melaksanakan pembangunan jalan akan menempuh beberapa cara untuk dapat menyelesaikan permasalahan ini dan pekerjaanpun dapat dilaksanakan kembali.

\section{Negosiasi}

Negosiasi merupakan pilihan pertama yang akan dipilih oleh kontraktor dan juga masyarakatAdat terkait penyelesaian sengketa tanah ulayat yang dihadapi oleh kedua belah pihak. Negosiasi dipilih karena dianggap akan lebih menghemat waktu dan juga biaya oleh kedua belah pihak. Di sisi lain negosiasi juga merupakan perwujudan kedekatan antara pihak kontraktor yang berada di lapangan dan juga masyarakat Adat yang memiliki tanah ulayat yang akan digunakan untuk pembangunan jalan. Hal ini berdasarkan perkataan salah satu kontraktor di lapangan yang mengatakan saat pembangunan jalan ini kontraktor harus mampu untuk melakukan pendekatan-pendekatan personal dengan masyarakat setempat. Sehingga dikemudian hari jika terjadi apa-apa dalam pelaksanaan proyek pembangunan tersebut masyarakat Adat dapat membantu untuk menyelesaikan persoalan yang mereka hadapi. Oleh karena itu saat di awal pelaksanaan pembangunan ada acara ramah tamah antara masyarakat Adat dan juga kontraktor yang bertujuan untuk mendekatkan mereka dan menjadikan mereka sebagai sebuah keluarga. Sehingga jika kedepannya terjadi sebuah permasalahan pada wilayah tersebut dapat dibicarakan atau diselesaikan secara kekeluargaan bersama.
Agar tidak merugikan pihak-pihak tertentu baik pihak masyarakat Adat maupun pihak kontraktor.

Negosiasi ini akan dilakukan langsung oleh kontraktor yang bertugas di lapangan dan juga pihak tertentu dari masyarakat Adat yang melakukan pemalangan pada proyek pembangunan jalan tersebut. Biasanya masyarakat yang bermasalah akan mendatangi lokasi pelaksanaan proyek pembangunan jalan dan mempertanyakan hak mereka terlebih dahulu kepada pengawas pelaksanaan proyek pembangunan jalan. Jika pengawas proyek tidak dapat mengambil keputusan atau sikap terkait tuntutan yang dilakukan oleh masyarakat, maka masyarakat akan segera mulai memalang pekerjaan jalan yang sedang dilakukan oleh kontraktor tersebut. Saat pemalangan dilakukan maka kontraktor harus segera menghentikan setiap kegiatan pelaksanaan pembangunan jalan tersebut. Apabila ada kontraktor yang nekat untuk tetap bekerja maka masyarakat Adat juga tidak akan segan-segan untuk menghentikan paksa dengan jalan kekerasan terhadap pekerja yang tetap bekerja.

Tahap pertama yang akan dilakukan oleh kontraktor ialah akan segera menghubungi tokoh keret yang mewakili masyarakat saat proses pelaksananaan upacara Adat dan juga penerimaan uang ganti rugi yang diterima oleh tokh keret tersebut. Hal ini perlu dilakukan oleh kontraktor dikarenakan tokoh keret ini adala tokoh kunci yang dimiliki oleh kontraktor tersebut untuk menjelaskan perihal apa yang sudah dilakukan oleh kontraktor beserta pemenuhan kewajiban-kewajiban yang telah dilakukan oleh mereka sebelum memulai pembangunan jalan tersebut. Tahap kedua, kontraktor beserta tokoh keret tersebut akan menemui pihak masyarakat Adat yang telah melakukan pemalangan jalan pada proyek yang sedang dilakukan oleh poihak kontraktor. Sesampainya di lokasi atau kediaman masyarakat adat yang melakukan pemalangan maka kontraktor beserta tokoh keret tersebut akan bertemu langsung dengan perwakilan pihak keluarga yang memimpin 
pemalangan jalan proyek pembangunan oleh kontraktor tersebut. Setelah pihak-pihak terkait bertemu langsung maka dipimpin oleh kepala keret akan mempertanyakan terkait alasan mengapa pemalangan jalan proyek pembangunan tersebut dilakukan oleh keluarga tersebut. Tahap ketiga ini yaitu saat kontraktor akan mulai mencoba menengahi permasalahan ini dengan cara memenuhi tuntutan dari masyarakat tersebut yang semata-mata bertujuan hanya untuk agar masyarakat tersebut mau untuk membuka palang jalan yang dilakukan oleh masyarakat Adat tersebut. Proses ini akan segera dilakukan oleh pihak kontraktor jika memang proses negosiasi yang dilakukan oleh tokoh keret tersebut tidak berhasil dilakukan.

Namun biasanya kontraktor akan menawar kepada masyarakat Adat terkait nominal yang ditentukan oleh masyarakat Adat tersebut. Hal ini dikarenakan terkadang tuntutan yang diajukan oleh masyarakat Adat tersebut dinilai terlalu besar sehingga kontraktor tentu tak akan sanggup untuk membayar tuntutan sesuai yang diminta oleh masyarakat Adat tersebut. Sehingga diantara kedua belah pihak tentunya akan kembali dilakukan perundingan terkait pembayaran nominal yang diminta oleh masyarakat Adat tersebut. Salah satu bentuk negosiasi yang dilakukan oleh kontraktor jika harga nominal yang diminta oleh masyarakat Adat terlalu besar maka mereka akan mencoba menggabungkan antara nominal yang tentunya jumlahnya akan dikurangi dan juga sebuah pengadaan peralatan yang tentunya dianggap perlu untuk menunjang kehidupan masyarakat tersebut.

\section{Mediasi}

Mediasi merupakan tahap lanjutan yang akan dilakukan oleh kontraktor jika memang melalui cara negosiasi tidak dapat menghentikan pemalangan proyek pembangunan jalan tersebut. Tahap mediasi ini akan melibatkan kontraktor, pihak bina marga selaku perwakilan pemerintah dan juga masyarakat Adat yang tengah memalang proyek jalan tersebut. Pelibatan bina marga adalah merupakan permintaan pertolongan kontraktor kepada pemerintah terkait problem yang sedang dihadapi. Di sisi lain pihak bina marga juga merupakan penanggung jawab langsung proyek pembangunan jalan tersebut. Sehingga untuk berbagai permasalahan yang berkaitan dengan perkembangan dan hambatan yang berhubungan dengan proyek pembangunan jalan tersebut perlu diketahui oleh pihak bina marga tersebut. Oleh karena itu jika memang proyek tersebut terhambat sampai tidak bisa dijalankan setelah melakukan beberapa upaya penyelesaian maka pihak kontraktor akan langsung meminta pertolongan kepada pihak bina marga sebagai penengah permasalahan ini.

Tahap pertama yang akan dilakukan kontraktor setelah gagalnya proses negosiasi adalah segera melaporkan kejadian ini kepada pihak bina marga sebagai pihak pemerintah yang bertanggung jawab langsung terkait pelaksanaan proyek pembangunan jalan ini. Biasanya akan ada perwakilan pengawas lapangan yangakan menemuipihak bina marga untuk menjelaskan secara detail penyebab dan juga tuntutan yang diminta oleh masyarakat Adat yang memalang pekerjaan jalan tersebut. Setelah mendengarkan problem yang disampaikan oleh masyarakat Adat tersebut selanjutnya pihak bina marga akan langsung mengajak kontraktor yang bersangkutan untuk kembali ke lokasi pemalangan jalan. Tahap kedua setelah kontraktor dan juga pihak bina marga tiba di lokasi pemalangan jalan ialah akan dikumpulkannya masyarakat yang melakukan pemalangan dan juga tokoh keret yang bertanggung jawab saat proses upacara adat beserta masyarakat Adat lainnya yang bias dijangkau. Selanjutnya dipimpin oleh pihak bina marga akan dilakukan musyawarah terhadap permasalahan yang terjadi di lokasi tersebut sehingga terhentinya proyek pembangunan jalan tersebut. Setelah kedua belah pihak memaparkan alasanalasannya maka selanjutnya pihak bina marga akan menjelaskan kepada masyarakat terkait status jalan tersebut. Yang dimaksud 
status jalan tersebut ialah bahwa jalan tersebut merupakan jalan yang dibangun oleh pemerintah untuk meningkatkan taraf hidup masyarakat setempat. Yang mana jalan tersebut diperuntukan kepada masyarakat Adat yang berada di lokasi tersebut agar akses bantuan dan juga sarana-sarana lain seperti kesehatan, makanan sehat yang memenuhi kebutuhan gizi masyarakat setempat dapat didatangkan ke wilayah tersebut.

Dalam mediasi ini tentu tidak selamanya berjalan mulus dan mendapatkan pengertian dari masing-masing pihak sehingga permasalahan bisa segera diselesaikan. Ada juga terkadang masyarakat sudah menurunkan jumlah harga yang diminta oleh kontraktor, namun tetap saja itu masih cukup besar bagi kontraktor untuk melakukan pembayaran sehingga kontraktor tetap tidak bersedia. Oleh karena itu maka pihak bina marga akan secara personal melakukan pembicaraan dengan pihak kontraktor terkait adanya sedikit perubahan pada kontrak pekerjaan yang disepakati antara kontraktor dan juga bina marga. Perubahan tersebut biasanya dilakukan berdasarkan perhitungan ulang dan analisa terhadap pekerjaan yang dilakukan di mana akan ada pengurangan pada bagian-bagian tertentu misalnya pada ketebalan aspal pada proyek pengaspalan pekerjaan jalan nanti. Yang mana anggaran yang dihasilkan dari perubahan kontrak tersebut akan digunakan untuk menambah uang tuntutan yang diminta oleh masyarakat Adat tersebut.

\section{Lembaga Adat}

Yang akan digunakan untuk pembangunan jalan tidak semuanya dapat dilakukan dengan melalui proses negosiasi dan juga mediasi oleh pihak pemerintah. Ada beberapa tanah ulayat tersebut yang dalam penyelesaian sengketanya menjadi sangat sulit dilakukan yang mana tentunya akan sangat menghambat sekali pelaksanaan pekerjaan jalan yang dialakukan oleh kontraktor tersebut. Penyelesaian sengketa tanah ulayat yang sangat sulit sekali dilakukan oleh kontraktor, pemerintah dan juga masyarakat ialah terkait sengketa tanah ulayat yang berkaitan dengan batas ulayat yang dimiliki masyarakat tersebut.

Sengketa pembangunan jalan terkait tanah ulayat yang berhubungan dengan batas tanah ulayat merupakan hal yang menjadi faktor teberat dalam pelaksanaan pembangunan jalan di wilayah Kabupaten Sorong. Penyelesaian sengketa tanah ulayat yang terjadi pada perbatasan tanah ulayat tidaklah semudah hanya memberikan ganti rugi kepada pihak masyarakat yang melakukan pemalangan terhadap tanah tersebut. Hal ini dikarenakan masyarakat tersebut juga akan membutuhkan pengakuan dari pihak keluarga lain yang telah mendapatkan ganti rugi terhadap tanah tersebut. Sehingga jika masyarakat tersebut tidaklah mengakui tanah tersebut bukanlah milik keluarga yang sedang memalang jalan tersebjt maka pemalangan jalan tersebut belumlah boleh dibuka. Di sisilain pihak yang telah mendapatkan ganti rugi juga mengakui bahwasanya tanah itu adalah milik mereka sehingga tidaklah perlu mereka untuk mengakui dan mendengarkan tuntutan dari pihak keluarga yang lainnya sehingga biasanya akan dilakukan sidang Adat.

Proses penyelesaian sengketa yang dilakukan melalui lembaga Adat ini tentunya akan sangat memakan waktu. Dikarenakan proses pelaksanaan sidang, pembuktian hingga keputusannya bisa memakan waktu sampai berbulan-bulan. Bahkan berdasarkan keterangan dari salah satu dewan Adat yang diwawancarai, proses sidang Adat untuk membuktikan kepemilikan hak tanah Adatbisa sampai memakan waktu dua tahun atau lebih. Oleh karena itu jika permasalahan sengketa tanah ulayat yang dihadapi oleh kontraktor sampai pada lembaga Adat atau sidang Adat maka pihak kontraktor dan juga pemerintah akan mengundur atau membatalkan pekerjaan jalan tersebut. Bisa jadi proyek pembangunan jalan tersebut akan melewati lokasi lain yang kemudian bisa diatasi permasalahan terkait tanah ulayat tersebut. 


\section{C.KESIMPULAN}

Terkait permasalahan sengketa tanah ulayat di Kabupaten Sorong Papua Barat terdapat beberapa faktor yang menyebabkan sehingga terjadinya sengketa antara kontraktor yang melaksanakan pembangunan jalan dan juga masyarakat Adat sebagai pemilik lahan. Adapun penyebabnya ialah pertama terkait tidak adanya pembebasan lahan yang dilakukan oleh pemerintah sehingga tanggung jawab tersebut diberikan kepada kontraktor. Selain itu ada juga penyebab dari kontraktor yang kadang lalai atau telat membayar uang pelepasan tanah Adat tersebut sehingga warga menjadi marah dan memalang jalan. Masyarakat Adat juga berperan terkait adanya sengketa tanah ulayat yang terjadi di wilayah mereka dikarenakan tidak jelasnya batas tanah ulayat yang dimiliki oleh masyarakat Adat tersebut atau bisa dibilang adanya pengklaiman dari kelompok lain terhadap tanah Adat tersebut. Selain batas yang sering dikalaim terkadang uang hasil penggantian rugi tanah ulayat juga tidak merata dibagikan kepada masyarakat Adat yang berhak sehingga memicu masalah dalam pelaksanaan pembangunan jalan tersebut.

Model penyelesaian sengketa tanah ulayat yang dilakukan dalam permasalahan sengketa tanah ulayat di Kabupaten Sorong Papua Barat ialah menggunakan jalur non litigasi. Penyelesaian itu dilakukan dengan proses awal negosiasi, kemudian jika belum selesai dilakukan dengan cara mediasi. Namun terkadang ada permasalahan yang dilakukan penyelesaiannya dengan melalui proses sidang Adat yang dilakukan lembaga masyarakat Adat setempat.

\section{DAFTAR PUSTAKA}

Buku

Heru Nugroho.(2001). Menggugat Kekuasaan Negara, Surakarta: Muhammadiyah University Press.

WinahyuErwiningsih.(2009).HakMenguasai
Negara Atas Tanah, Yogyakarta: Total Media.

G.Kertasapoetra dan kawan-kawan.(1985).

Hukum Tanah Jaminan UndangUndang Pokok Agraria Bagi Keberhasilan Pendayagunaan Tanah. Jakarta: Bina aksara.

\section{Internet}

Jawa Pos, Strategi Pemerintah Dorong Pembangunan Infrastruktur Dalam Negeri, https://www.jawapos.com/ read/2017/12/15/175059/strategipemerintah-dorong-pembangunaninfrastruktur-dalam-negeri, diakses tanggal 18 Februari 2018

Media Indonesia, Keterbatasan Akses Jadi Masalah Wisata di Papua, http://mediaindonesia.com/read/ detail/4181-keterbatasan-akses-jadimasalah-wisata-di-papua, diakses tanggal 18 Februari 2018

Hendra Kusuma - detikFinance, Ada Jalan Trans Papua, Masyarakat Pedalaman Makin Mudah ke Kota https:// finance.detik.com/berita-ekonomibisnis/d-3519269/ada-jalan-transpapua-masyarakat-pedalamanmakin-mudah-ke-kota, diakses tanggal 18 februari 2018

\section{Peraturan perundang-undangan}

Undang-Undang Nomor 5 Tahun 1960 tentang Peraturan Dasar PokokPokok Agraria, Pasal 3.

Uu no 2 tahun 2012 